\title{
Presupposition and the Implicit Display Theory
}

\author{
Ibtesam AbdulAziz Bajri ${ }^{1}$ \\ ${ }^{1}$ Assistant Professor of Sociolinguistics, King Abdul Aziz University, Jeddah, Saudi Arabia \\ Correspondence: Ibtesam AbdulAziz Bajri, Assistant Professor of Sociolinguistics, King AbdulAziz University, \\ Jeddah, Saudi Arabia
}

Received: October 27, 2015

Accepted: December 6, 2016

Online Published: December 13, 2016

doi:10.5430/elr.v5n4p40

URL: http://dx.doi.org/10.5430/elr.v5n4p40

\begin{abstract}
Presupposition is one way of expressing irony which is a communicative behavior in that the literal meaning and background assumptions associated with an utterance differ in systematic ways from the reality as assumed by the interlocutors. Typically, the intended meaning of ironical utterances is the opposite of the literal meaning. Irony is perceived through a complex interaction between an utterance and its context and sense many social functions. The purpose of this paper is to explore the presupposition role in the recognition of irony in Middleton (1989) cynical tragedy. The issue of controversy in irony research depends on what features of irony people endorse. Thus, a more comprehensive view of irony, the implicit display theory of verbal irony is herewith proposed. Discussion of the findings suggests that implicit display theory and the tool of presupposition can account for indirect effects on the degree of irony.
\end{abstract}

Keywords: Presupposition, Irony, Pragmatic inference, Implicit display theory

\section{Introduction}

Presupposing expressions are those which assume rather than assert information. Technically speaking, Giltrow (1996) indicates that "elements presupposed rather than asserted survive negation: they are removed from the domain of contradiction, sequestered from controversy. Practically speaking, presupposed elements are those which the writer assumes to be in some way familiar to the reader" (P. 217). She emphasizes that many readers share knowledge, information and conditions that are well-known. Entities and characters are well-known and infer the existence of which the man is identified. Inference arrangements are efficient to presuppose rather than asserting the existence of entities. Everyday live speeches are achieved by presupposing rather than asserting (P. 217).

According to Schwarz (2016) "presuppositions are at the very nexus of linguistically encoded content and contextual information, as they relate directly to the discourse context but also interact in intricate ways with their intra-sentential linguistic environment" (P. 274).

BeYssade (2013) claims that there is "a weak uniqueness presupposition" in which the definite noun phrases "don't presuppose the uniqueness of their referent" (P.124). Hence, I can say that there is a strong uniqueness presupposition, which represents "the amount of information assumed to be known by participants (background knowledge, common ground) and has direct impact on how much is explicitly said and how much remains implicit" (10 Pragmalinguistics and Stylistics).

Presupposing expressions are kind of pragmatic inferences. Levinson (1983) indicates that the "technical sense of presupposition is restricted to certain pragmatic inferences or assumptions that seem at least to be built into linguistic expressions and which can be isolated using specific linguistic tests" (P. 168). He adds that pragmatic presuppositions, "are best described as a relation between a speaker and the appropriateness of a sentence in a context" (P. 177). Polyzoui (2015) asserts that presupposition as a background-setting device is prototypical, but it is not exclusively based on sentence level (contra traditional dentitions which focus only on sentence-level presupposition (P. 124). Furthermore, Garcia-Odon (2016) "predicts that if a potential presupposition entails - or it is inferred that it entails - just one of the constituent clauses of a clause which is itself compound (or the negation of a clause, if the sentence is a disjunction), the presupposition will be conditionalized to that clause" (P. 155).

Spector (2016) uses Middle-Kleene theory of presupposition, following Stalnaker's (1978), an assertability condition. According to Spector, Middle Kleene is used as "a bridge from the computation of truth-values to a notion of felicity involving in one way or another common knowledge. A sentence's presupposition is usually viewed as defining its 
felicity conditions, and more specifically, as constraining what the common ground between speaker and addressee must be for the sentence to be felicitous" (P. 47).

Various theories of pragmatic presupposition "utilize two basic concepts in particular: appropriateness (or felicity) and mutual knowledge (or common ground, or joint assumption) in the way indicated in the following definition:

An utterance A pragmatically presupposes a proposition B if A is appropriate only if B is mutually known by participants" (Levinson, 1983, PP. 204- 205).

In accordance to Utsumi (2004), "[i]rony is a fascinating pragmatic phenomenon whose processing involves complex interaction between linguistic style and contextual information. There are also good reasons for probing the mechanism of irony processing in cognitive science. First, irony offers an effective way of accomplishing various communication goals for maintaining and modifying social and interpersonal relationships that are difficult to do literally. Second, irony processing requires higher-order mindreading ability (Happe, 1993), which has been argued to play an important role in the interpretation of ordinary utterances (Wilson and Sperber, 2004). Third, as Gibbs (1994) argues, an ironic way of talking about experiences reflects our figurative foundation for everyday thought" (P. 1369).

Irony is briefly defined as "the figure of speech that conveys the opposite meaning of what is literally said" (Jeoung). While Kotthoff, (2003, P. 1388) stated that Quintilian (1975) proposes that irony is a type of allegory in which the opposite is expressed. The Romans call it "illusion" (mocking). One recognizes this either from the tone in which it is spoken or from the person affected or from the nature of the subject, for if something contradicts what is said , it is clear that the speech wishes to say something different. Further, Kotthoff, (2003, PP. 1388-9) asserts that Lapp (1992, P. 24) summarizes the ancient concept of irony as follows:

1. What is said is the opposite of what is meant.

2. One says something other than what one thinks.

3. Criticism through false praise, praise through apparent criticism.

4. Every type of making fun and ridicule.

Kotthoff (1998) says that "an ironic utterance has two meaning levels which must be processed: the said and the implicated" (P.1). It is "perceived through a complex interaction between an utterance and its context and serves many social functions as to be sarcastic and to be humorous (Utsumi, 2004, P. 1369).

Kotthoff (2003) states that "[m]any linguists regard irony as an aggressive form of communication ... Brown and Levinson (1987) and Barbe (1995) have maintained to the contrary, that ironic critique is less face threatening than direct utterances. They thus view politeness as a reason for using irony" (P. 1389).

This paper seeks to use presupposition in explaining why the irony of politeness is expressed the way it is, and how it involves people showing they think well of others, in the meanwhile they don't! That is, how the location embodies the illocution in Women Beware Women; which is written by Thomas Middleton in the early 1600s.

\section{Method of Analysis}

In order to provide an analysis of the potential factors of irony that could explain why in many instances irony is preferred over directly stating the literal meaning, I'm using Gussow (1987) explanation of the play and also a more comprehensive view of irony which is the implicit display theory of verbal irony (Utsumi, 2000 and 2004). According to the implicit display theory, style of an ironic expression is used to assess to what degree a specific ironic utterance is similar to the prototype of irony, while contact motivates the addressee to interpret an expression ironically (Utsumi, 2004, P. 1369).

\subsection{Implicit Display Theory}

The implicit display theory takes a comparative view that irony is a prototype-based category, which is the idea underlying cognitive linguistic research. Another point is that it claims a differential role of style and context. The main claim of the implicit display theory is threefold:

First, irony presupposes ironic environment, a proper situational setting in the discourse context. Ironic environment consists of:

(a) speaker's expectation

(b) incongruity between the expectation and the reality

(c) speaker's negative attitude towards the incongruity 
Second, irony is an utterance that implicitly displays ironic environment. Implicit display of ironic environment is achieved by an utterance which:

(d) alludes to the speaker's expectation

(e) includes pragmatic insincerity by violating one of pragmatic principles

(f) expresses indirectly the speaker's negative attitude by being accompanied by ironic cues

Third, irony is a prototype-based category formulated by the notion of implicit display. The prototype of irony is an abstract exemplar which fully meets all the three conditions for implicit display. The degree of irony can be assessed by the similarity between the prototype and a given utterance with respect to the three conditions (Utsumi, 2004, PP. 1369-1370).

\subsection{General Hypothesis}

In accordance to the study and experiments conducted by Utsumi (2004), the implicit display theory posits the hypothesis for irony processing, which is summarized in Figure (1) below. "On the one hand, style of an ironic sentence, which corresponds to properties of implicit display, governs how similar it is to the irony prototype, i.e., the degree of irony. On the other hand, context determines how likely one is to make an ironic remark, i.e., likelihood of irony, based on to what degree each of the three constituents of ironic environment holds in that context" (P. 1370).

The implicit display theory emphasizes the hypothesis for irony processing, which is shown in Figure (1):

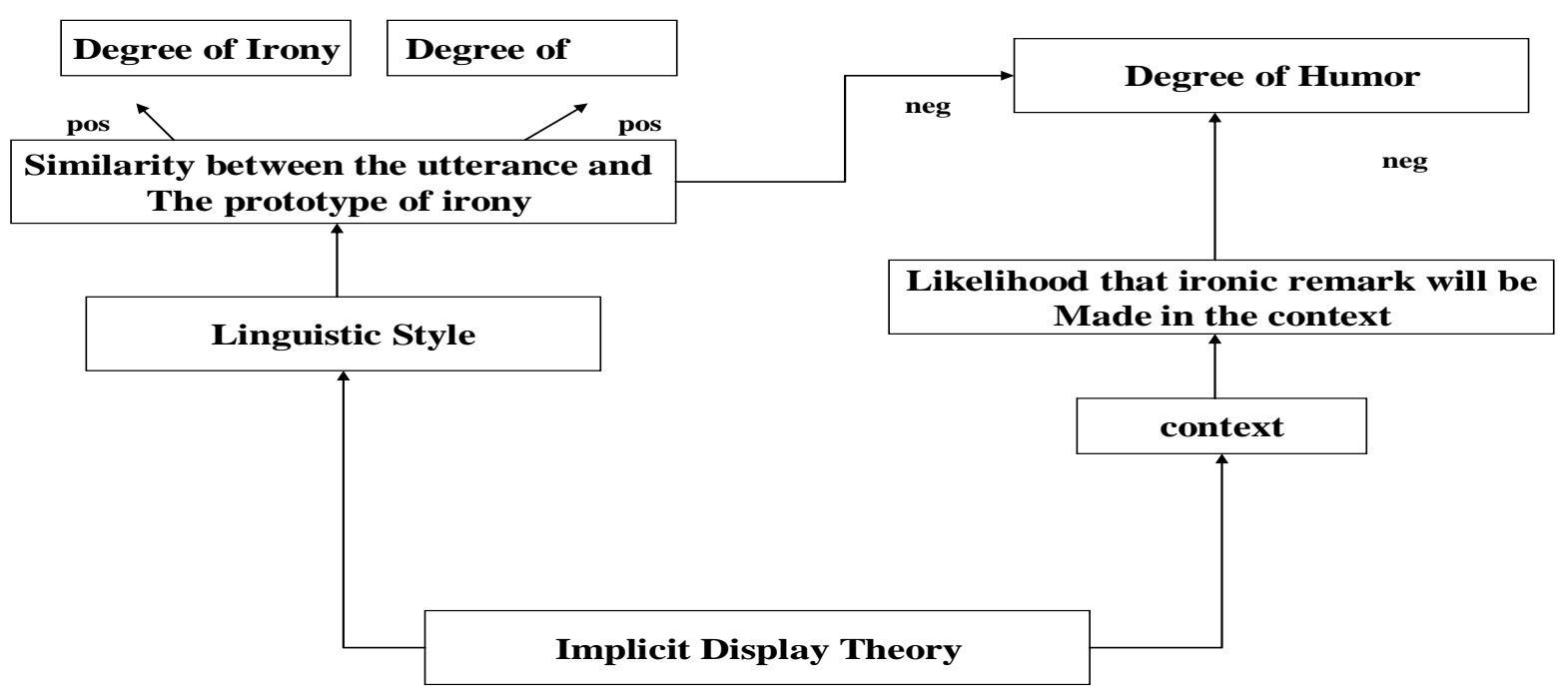

Implicit Display

Ironic Environment

Figure 1. General hypothesis for irony processing elicited form the implicit display theory

The degree of irony is affected by linguistic choices, not by contextual setting, and it is high to the extent that the properties of implicit display are satisfied. Furthermore, it is reasonable assumed that the degree of sarcasm of ironic utterances proportionally depends on the degree of irony because sarcasm is often conveyed in the form of irony. It is therefore hypothesized that the degree of sarcasm of an ironic utterance is affected only by linguistic style and it is high to the extent that the properties of implicit display are satisfied. Unlike irony and sarcasm, how the degree of humor is determined cannot be directly explained by the implicit display theory.

Utsumi (2004) therefore adopts an incongruity-resolution model of humor (Attardo, 1997), a cognitive model widely accepted in humor research. "The incongruity-resolution model argues that humor involves an incongruity between what was expected based on our conceptual pattern and what occurs in the humorous event, which is often expressed by a punch line in humorous texts" (P. 1370).

According to the implicit display theory, "ironic utterances involve two kinds of incongruity: (a) incongruity between an expected type of utterance (e.g., ironic or literal) and the actual type of a given utterance (i.e., irony in this paper), 
degree of which is inversely related to the likelihood of irony; and (b) incongruity (i.e., dissimilarity) between the irony prototype and a given ironic utterance. If the incongruity-resolution model and the implicit display theory are plausible, a general hypothesis about the degree of humor is as follows: the degree of humor or an ironic utterance is affected by both linguistic style and context, and it is high to the extent that a discourse context is incongruous to the ironic environment or that the utterance is dissimilar to the irony prototype" (PP. 1370-1371).

On the other hand, style of an ironic sentence, which corresponds to properties of implicit display in Women Beware Women, it's shown to the ironies of expressions are expressed in the form of presupposing expressions in the play. The implicit display theory mentions the following predictions on the effects of context in the above play:

- Neither negativity nor ordinariness has an effect on the degree of irony and sarcasm.

- Ironic utterances in a weakly negative context are more humorous than those in a strongly negative context.

- Ironic utterances in a usual context are more humorous than those in an unusual context as explained in the play.

Using presupposing expressions of linguistic styles in this play, the interactions create the ironies of politeness environment.

On the one hand, style of an ironic sentence, which corresponds to properties of implicit display, governs how similar it is to the irony prototype, i.e., the degree of irony. On the other hand, context determines how likely one is to make an ironic remark, i.e., likelihood of irony, based on to what degree each of the three constituents for ironic environment holds in that context.

\section{Application of the Implicit Display Theory}

In the story, Women Beware Women, the researcher finds dense populations of linguistic features that contribute to a larger set of expressions: "politeness" expressions. First and foremost, the play is full of ironic instances, in the story itself and its style. Thus, the researcher concurs with Giltrow (1996) that "politeness does not only include courtesies but suppressions too, as well as tacit gestures by which people recognize one another in their range of social distinction, by which people indemnify themselves and sustain advantage" (P. 215). The linguistic feature of "presupposing expressions, which assume rather than assert" (Giltrow, 1996, P. 215) is considered as a good contributor to politeness and used in this investigation.

The linguistic features that are shown in the play can be given in stylistic and contextual effects in irony processing the implicit display theory. I will cite herewith an illustration taken from passages of the play, Women Beware Women, how implicit display theory is applied following above threefold claim.

Prototype - Context: Leantio feeling insecure while expecting loyalty and faithfulness from Bianca

Leantio: Come forth, Bianca. Thou art betrayed, I fear me. The Duke knows thee.

Bianca: How should the Duke know me? Can you guess, mother?

Leantio: Thou has been seen, Bianca, by some stranger. Never excuse it.

Bianca: I'll not seek the way, sir. Do you think you have married me to mew me up not to be seen? What would you make of me?

Leantio: A good wife, nothing else.

Bianca: Why, so are some that are seen every day, else the devil take 'em.

Leantio: No more, then. I believe all virtuous in thee without an argument. "Twas but thy hard chance to be seen somewhere. My heart flames for it! Yet let's be wise and keep all smothered closely. I have bethought a means. Is the door fast? You know, mother, at the end of the dark parlour there's a place so artificially contrived no search could ever find it. There will I lock my life's best treasure up. Bianca!

Bianca: Would you keep me closer yet? Have you the conscience?

Leantio: Why are you so insensible of your danger to ask that now? The Duke himself has sent for you! (PP. 22-24).

Based on above exchange of conversations, Leantio has actually said ironically in various ways to his wife Bianca whom he suspects as having been seen by the Duke while he's away or during his one-week absence from his home, and moreover he doubts she's telling the truth.

1. Opposition statement: "I believe all virtuous in thee without an argument."

2. A true assertion: "A good wife, nothing else." 
3. Rhetorical question: "Why are you so insensible of your danger to ask that now?"

4. Circumlocutory utterance: "Yet let's be wise and keep all smothered closely."

In order for an utterance to be interpreted ironically, the implicit display theory argues, the discourse situation must be identified as ironic environment through the process of checking of inferring these constituents.

In the scene presented above, Leantio entertains some kind of belief that Bianca and his mother are all kept smothered closely at home. Further, he demands and expects loyalty from his wife Bianca which is just normal particularly to newlywed like them. But then his expectation is not fulfilled, thus getting disappointed when he learns that Bianca is seen by the Duke. This situation is thus identified as ironic environment.

Further, the utterance by Leantio, "I believe all virtuous in thee without an argument." satisfies the three conditions of implicit display and presupposing expressions. First, it mentions, and thus alludes to Leantio's expectation of Bianca's good moral character. Second, it is a literally false statement that violates the maxim of quality. Third, the utterance of word "all" is highly impossible as nothing on earth is absolute thus, considered ironic.

It's understandable though it may seem ironical that Leantio is greatly affected and quite upset, yet instead uttering an opposition statement, a sweeping declaration of commendable quality or moral excellence to Bianca just to stop further argument yet, at the back of his mind he doubts her and that he knows Bianca owes him an explanation.

Further, a rhetorical question, "Why are you so insensible of your danger to ask that now?" is posed by Leantio to Bianca about her insensitivity to the danger but this is asked only for the sake of persuasive effect rather than as a genuine request for information. Thus, the speaker, Leantio is implying that the answer is too obvious to require a reply since the more accurate answer is coming only from him, based on his own assessment of the situation.

Finally, let us consider the circumlocutory statement, "Yet let's be wise and keep all smothered closely." It sounds indirect with the use of unnecessary words to express an idea. It can be interpreted ironically, but its degree of ironicalness may be much smaller than the typical type of irony, "I believe all virtuous in thee without an argument." This difference can be explained in terms of to what degree of an utterance achieves the implicit display. The circumlocutory statement is only weakly related to the speaker's expectation by a number of coherence relations, whereas the opposition statement directly refers to the expectation. Furthermore, the circumlocutory statement is pragmatically insincere to a much lesser degree than the opposition statement including an apparent violation.

\section{Discussions}

The following is a detailed discussion of several contexts of irony of politeness as read from the play. It is proportionally allocated in accordance to their contexts in relation to the three contributors of politeness expressions. As for me, I have read numerous references and related texts as sources of information and studies that helped me acquire general knowledge about how the characters of the play communicate.

The beginning of the play often presupposes things. Characters are named as if the reader knows who they are; entities are referred to with definite determiners as if they are known to the reader (Giltrow, 1996, P. 217). Crucially, negation of an expression does not change its presuppositions even when expressed negatively from positive viewpoint.

From the following examples of presuppositions, politeness expressions are to be given their ironic meanings in accordance to the guidelines deem necessary under the circumstance.

\section{Context (1): The welcoming of Bianca}

Leantio brings home Bianca from Venice to Florence and introduces her to his mother.

Mother: "What's this gentlewoman?"

Leantio: "Oh, you have named the most under valued'st purchase, that youth of man had ever knowledge of! As often as I look upon that treasure, and know it to be mine, it joys me that I ever was ordained to have a being, and to live amongst men! I must confess I am guilty of one sin, mother, more than I brought into the world with me; but that I glory in; 'tis theft, but noble as ever greatness yet shot up withal." (p. 1).

Irony: It sounds like Leantio is humbling himself by acknowledging that he has committed the best piece of theft. Never mind the use of lavish praises and bombastic words to describe Bianca, it could be taken for granted especially coming from someone who loves and idolizes her too much. Leantio likened Bianca to a precious acquisition as a jewel in his eyes to be kept and well taken care of. Though he has taken away Bianca from her parents without their consent, Leantio is unrepentant instead he wants to justify his action as worth doing under the circumstance. 
However, isn't it ironic that whosoever has committed a crime or theft particularly will keep his mouth shut or remain silent to keep it a secret? So it seems like Leantio is overwhelmed, and his bragging about his theft of Bianca could be understood as just a front to cover up his apprehension. Since Bianca's parents are enraged like storm when she runs away from home with Leantio, therefore, there's a possibility that she could be taken back by her parents. Or it could be that because of Bianca's extra-ordinary beauty, she will be vulnerable to attack by outsiders especially by someone of higher status.

The question, "What's this gentlewoman?" presupposes that there's a gentlewoman in front of the mother that she wants to know who she is. It may sound just a normal inquiry but the Mother is actually rude when she cannot wait to be introduced to Bianca.

Further, the comparative word 'more' implies comparison from the past to the present event. Making comparisons will pave the way for digging up the dirt of the past and that something has to be done.

\section{Context (2): On the status quo and family upbringing of Bianca}

Leantio's mother is questioning and reminding him of the situation upon learning that Bianca comes from a wealthy family, that Bianca is used to live a comfortable life. And that not only love and affection could sustain a happy married life.

Mother: "You know not what you have done. What ableness have you to do her right, in maintenance fitting her birth and virtues, which every woman of necessity looks for, and most to go above it, not confined by their conditions, bloods or births, but flowing to affection, wills and humours?"

Thus, Leantio has quoted to his mother, "Speak low, sweet mother; you are able to spoil as many as come within the hearing. I pray do not you teach her to rebel, when she's in a good way to obedience. I'll prove an excellent husbandhere's my hand-lay in provision, follow my business roundly, and make you a grandmother in forty weeks! Go, pray salute her, bid her welcome cheerfully" (P. 2).

Irony: The mere declaration of doubt of Leantio's mother about his capability to provide life of comfort and luxury to Bianca is acceptance of reality and considered a politeness to look for the welfare of someone.

However, it is ironic that there's a mother who is not happy with his son's marriage to a beautiful young lady coming from a wealthy family, when most mothers would surely appreciate such feat. Instead, the mother is pointing out the possible adversities, the financial difficulties the new couple may be facing in future.

Although the mother explicitly voices out her displeasure, she is in fact could have been only just testing the waters to see the initial reaction of Bianca. Asking question like 'what ableness...' is like expressing concern but requiring assurance though the irony will be that there's underestimation of capability leading to hesitation, apprehension and non-acceptance.

\section{Context (3): Call of duty and bidding farewell to Bianca}

Bianca: "I perceive sir, you are not gone yet. I have good hope you'll stay now."

Leantio: "Farewell, I must not."

Bianca: "Come, come pray return. Tomorrow, adding but a little care more, will dispatch all as well-believe me, it will, sir."

Leantio: "Alas, I'm in for twenty if I stay. Again, farewell to thee... (P. 7).

Irony: It's undeniable that Leantio and Bianca are happy with each other with the way they exchange conversation. Leantio makes the right decision to finally bid farewell and leave for work duty though heavy in his heart after some pleadings from his wife to stay. He let sense of responsibility towards duty prevailed over his own enjoyment.

The irony comes unexpectedly from the mother though whose message is full of concern and advice it is uttered sarcastically but with awakening reality. Whatever the real reason for offering such advice to Bianca is just meant to show her that his husband does not own his time.

The utterances of 'come' and 'return' imply or assume that Leantio is around yet and may be persuaded to stay and not leave home after all. It's nice to hear of these words coming from a wife whether uttered sincerely or not. But if she will prevail over Leantio, the implication will be neglecting obligation and commitment to duty in exchange of personal happiness.

Application of implicit display theory: Linguistic style (Sentence type factor)

Opposition: I have good hope you'll stay now. 
Rhetorical: nil

Circumlocution: Come, come pray return. Tomorrow, adding but a little care more, will dispatch all as well-believe me, it will, sir.

Ironic Environment: It's evident that Bianca gets disappointed after having failed to persuade Leantio to stay so she just downplays her insistence and she agrees though deep in her heart she's not happy. Thus, her opposition statement of expectation is reduced to a mere hope and this in itself presupposes an ironic environment as her utterances are seen as last-ditch effort, hoping against hope that she will prevail but to no avail that she finally concedes, $\underline{\text { since it }}$ must, farewell, too...'

Even the absence of rhetoric does not lessen the degree of irony in this context. Rhetoric is not essential in this particular context, in the first place there's not particular utterance or an opportunity that calls for it to be expressed by Bianca does not occur.

Bianca's circumlocutory statement as above is only weakly related to her expectation; it's reduced to just well-wishes and self-assurance which is common for newly married couple. Therefore, the degree of ironicalness is much smaller than an opposition statement since it must be viewed as half-assertion when we can also perceive that it is uttered out of desperation and a good way out to show concern and acceptance.

\section{Context (4): Showing Bianca the monument}

Livia: "I beseech you show 'em her, that will beguile time well. Here, take these keys, show her the monument too and that's a thing everyone sees not, you can witness that, widow!"

Bianca: "Kind lady, I fear I came to be a trouble to you, and to this courteous gentleman that wears a kindness in his breast so noble and bounteous."

Guardiano: "If you but give acceptance to my service, you do the greatest grace and honour to me that courtesy can merit."

Bianca: "Trust me, sir, mine eye never met with fairer ornaments."

Guardiano: "There's a better piece yet, than all these... (enter unseen the Duke) (PP. 16-17).

Irony: From the start, there's already an insinuation to beguile Bianca's time well, so as to buy time to be able to carry out the evil plan as scheduled. The unsuspecting Bianca never doubts sincerity of the people around her. Since she is curious enough to visit the rooms, she gets no hint to what danger she is getting into. For Guardiano, the showing of monument is a routine part of the visitation designed to trap unsuspecting victim.

Livia seems so hospitable and too good to be true. There's no any chance to doubt her particularly when she advises Guardiano to beguile time well with Bianca. Therefore, the term 'beguile' here is used ambiguously by Livia, this is where the irony lies when she actually means to buy time to serve its purpose and not to pass time pleasantly as meant to be. The fact is that even the Mother hasn't seen this 'monument' yet considering she's an old timer in the neighborhood is also ironical. It's because this monument is reserved exclusively for all Duke's good prospects to see, which everyone sees not.

Further, it's ironical that the Mother who's supposed to keep watch of Bianca for her son seemingly connives with Livia to keep it as top secret for Leantio to avoid his fury.

It appears that the 'monument' refers to the Duke himself. This term is also used to represent something like a statue, to be idolized or appreciated though made of stone standing erect and immovable that could do no harm but it happens to be the exact opposite, it's a living monument.

In the utterance, 'show her the monument too', the word 'too' is implying that something important reserved for sighting by Bianca. This is intended as part of the plan though Livia advises it in a way just to remind Guardiano not to forget showing the monument since this is the main part of the visit. However, Bianca will never suspect that there's evil plan lay in waiting for her.

While utterance of 'better yet' is meant to entice that things will look convincing so that Bianca will become anxious or eager enough to see what's that 'better' piece is all about. The irony here is in the motive as there's not other way to say especially if one is keen on implementing her evil devise.

\section{Context (5): The disappointment of Leantio}

Bianca: Oh, sir, you are welcome home.

Leantio: Is that all? Why this? Sure you are not well, Bianca. How dost, prithee? 
Bianca: I have been better than I am. Nay, I have been worse, too, that now you see me, sir.

Leantio: I'm glad thou mend'st yet. I feel my heart mend, too. How came it to thee? Has anything disliked thee in my absence?

Bianca: No certain... I have had the best content that Florence can afford... Methinks this house stands nothing to my mind. I'd have some pleasant lodging in the high street, sir. (PP. 21-22).

Irony: It seems that Bianca has lost every feeling of affection towards Leantio. Her formal manner of conversation with Leantio is like distancing or detaching herself from Leantio. And this does not escape from Leantio who manages to question her attitude yet keeping his cool out of love and concern for her. All of a sudden, she becomes more mature, serious and ambitious. Behind those seemingly polite utterances of Bianca are all lies but only just getting near to confess something. Yet her aspirations for a more comfortable life almost betray her present state of mind.

However, this manner of discussion with Leantio will drag on indefinitely until Bianca has taken all the courage awaiting for the appropriate time. In fact Bianca is posing provocative response to the dismay of Leantio. Whenever they get near to clearing their conversation, Bianca suddenly shifts topics that even Leantio is unable to detect. It's ironic that Leantio could not decipher the way Bianca answers him but just maintaining his cool though obviously upset. But Leantio is not ignorant not to sense something wrong, he is greatly affected and disappointed with the way Bianca treats him.

The utterance, 'some pleasant lodging in the high street' implies existence of lodge in the vicinity. But the question who is providing the lodging to Bianca, and why? This comes as a surprise to Leantio but soon alarms sensing that Bianca is insinuating something better residence when not long ago she's been satisfied to live at a simple house. Though Bianca is not ready yet to make confirmation about ongoing understanding with the Duke, she's still buying time trying to be evasive by giving indirect answer each time Leantio asks her.

Application of implicit display theory: Linguistic style (Sentence type factor)

Opposition: I should delight to see none but yourself.

Rhetorical: Has anything disliked thee in my absence?

Circumlocution: Withdraw you, Bianca, thou art a gem no stranger's eye must see, however thou please now to look dull on me.

Ironic environment: Leantio's opposition statement smacks of irony for being able to sound romantic though he wants so much to explode with anger. He is expecting a warm welcome from Bianca after a week-long absence but only gets disappointment since he feels no reciprocal excitement coming from Bianca. However, he is met only by Bianca with cold treatment and formal greeting without intimacy. Though he's quite upset manages to stay cool yet he's also affected that cannot control confronting Bianca to satisfy himself.

The rhetorical question is necessary but not timely since Bianca will surely choose to keep silent for obvious reason. Though Bianca is not ready yet to make confirmation about ongoing understanding with the Duke, she's still buying time trying to be evasive by giving indirect answer each time Leantio asks her. So that Leantio will have to tolerate with a no response coming from Bianca. Thus, it's less ironic and less sarcastic than an opposition statement.

The circumlocutory statement as above is a side comment that serves to support an opposition statement. It has no direct relation with the disappointment that is felt by Leantio but only a plan to shield Bianca from stranger's eye. It's less ironic and less sarcastic than the rhetorical statement.

\section{Context (6): The other side of Cardinal}

Cardinal: Stop your philandering, I said. I said the public do not like to see this in their governor, but they do! I was wrong there. No, carry on, $\underline{I}$ was wrong to reprimand him! There, church dignitary bows to insatiable appetite of prince ....

Duke: What? I've done it all. (PP. 34-35).

Irony: It's sad that even the Cardinal who is supposed to act as the conscience and spiritual adviser of the immoral Duke engages himself in lurid discussion with the Duke. For a while, the Cardinal becomes pessimistic in his outlook. He feels defeated when the public adores their philandering governor while preaching him righteousness, the moral values of being loyal and faithful. It's ironical that instead of persuading the Duke to follow his advice, the reverse happens. In a manner of speaking, it seems the Cardinal ends up agreeing with the Duke's actuations. Cardinal becomes tolerant and even suggestive of some offensive utterance and actions. 
However, we might get fooled by the way some of Cardinal's utterance is meant to be understood. It's not as morally righteous as it should be rather it should be interpreted the other way around. Cardinal's utterance is ironical which is similar to using psychological warfare intended to reduce an opponent's morale, as if sharing the same belief but is done only for the time being just to avoid facing outright opposition. However, Cardinal is not at his best when he starts initiating discussion with obscene and disturbing ideas to the great enjoyment and appreciation by the Duke which Cardinal is unable to undo later.

The utterance of the word 'wrong' in 'I was wrong to reprimand him' is a commentary adjective that imply Cardinal is frustrated by the way things turn out. This acknowledgement is in deference to public opinion. However, Cardinal may actually insist that he's morally correct after all. That if he only has his way, he would keep on reprimanding the Duke.

Application of implicit display theory: Linguistic style (Sentence type factor)

Opposition: Stop your philandering, I said. I said the public do not like to see this in their governor, but they do! I was wrong there. No, carry on, I was wrong to reprimand him!

Rhetorical: nil

Circumlocution: Yes, I do not doubt it, though this I think of something else. Something which unlocks the discipline of the civil state.

Ironic environment: Cardinal being the spiritual adviser to the Duke is very vocal to reprimand him to the extent that he proves himself wrong since the public just adores their Duke for whoever he is. So the good Cardinal feels his expectation that the public shares his sentiment against the Duke has failed thereby getting disappointed with the public but not to the Duke. But Cardinal is wrong since the Duke is really serious to remain committed to Bianca, the love of his life at the moment. So ironic environment is shown here with failed expectation and subsequent frustration by the Cardinal that he utters in exasperation those sarcastically but seemingly polite words that show the other side of him, able to speak in words that could offend no one, not even the Duke.

Again, there's no opportunity for rhetoric to arise in this context. Perhaps the situation is not conducive and too obvious to try not to question the Duke any further.

The circumlocution that is stated above does not directly allude to Cardinal's expectation. It's an understatement or just a diversion of topic that is weakly related to the expectation but assumed to be more sincere than the opposition statement.

\section{Context (7): The strange vision or dream of Sordido}

Sordido (to Leantio): Plot with me. I shall burst into the wedding and take the impeccable by force. My first and only entrance to the gateway of all life and death. In her washed matrimonial skin, all scented for the state and bishop's twittering, I'll force her. Down on some polished marbles in foams of lace and splitting fabrics I'll... her place!

(Pause) There, forget I spoke. Only a vision. I am liable to visions. Comes of poverty and weird alcohols... (P. 49).

Irony: Sordido has this unusual vision on the day of Duke's wedding to Bianca. His plan is to take Bianca by force and ravage her. He's suicidal knowing that he will face death for doing his mission. Bianca surely does not deserve this planned evil treatment from a guy he hardly knows? This is really strange but his hatred is deeply rooted from his displeasure to the Duke. So his way of punishing the Duke is to take away from him his beloved Bianca.

This is yet another irony that Leantio does not bother to discourage or thwart the evil plot of Sordido on Bianca. By not dissuading Sordido against the plot, it's as if Leantio actually encourages or indulge himself by being tolerant of the plot. We understand Leantio's indignation which is caused by Bianca deserting him in favor of the Duke but not of Sordido's annoyance on her.

Sordido confesses this plot to Leantio but later recants or dismisses it as just only a vision as a result of his impoverished state and spirits of alcohol. There is yet pretense of politeness but he cannot take back what he has already said to Leantio. There's sense of politeness when one is trying to downplay what has been harshly said earlier as if to erase if not dilute the effect of the utterance.

The utterance by Sordido of the words 'first and only' in 'my first and only entrance', presupposes that after the first then will come next the second. But with the combination of word 'only' it intensifies the presupposition. This shows eagerness of Sordido to implement his plan. The irony is that he may not be given the second chance, and should have said 'my last' entrance. 


\section{Context (8): Hating or pitying Bianca}

Leantio: You hate Bianca and dress up revenge as politics!

Livia: Hate her? No, I pity her. It's you who hates.

Leantio: Pity? You? Pity's not a quality I'd pin to you.

Livia: Pity, yes. Pity her who uses..., to buy her way up floors of privilege. When Sordido forced his pain on her she'll learn the thing she sells can just as well be stolen... (P. 52).

Irony: 'Pity' here is the word used ironically. How can Livia claim to have a pity in her heart when what she wants is to ruin Bianca? Not even sympathy could apply towards her feelings to Bianca. After all, Leantio is right in accusing Livia as the one having more hatred on Bianca. For whatever reason, Livia has no right over Bianca though she is the one who devises a scheme for the Duke leading to seduction of Bianca and her triumphal entry to becoming a duchess. The truth of the matter is that Livia is envious of Bianca's success. She doesn't want Bianca to become duchess so she is justifying her action as worth doing.

The utterance of 'hate her?' by Livia in response to Leantio is meant to deny her real feelings toward Bianca since it is posed as a question. But this is ironical since Livia will never acknowledge it thought she has valid reason to hate Bianca because of Leantio.

Application of implicit display theory: Linguistic style (Sentence type factor)

Opposition: No, I pity her. It's you who hates.

Rhetorical: Hate her?

Circumlocution: Pity her who uses..., to buy her way up floors of privilege.

Ironic environment: Livia's opposition statement is quite insincere even if she tries to mince her words appear to be less critical. As a matter of fact she tries hard to hide her true feelings toward Bianca and she cannot let it obvious to Leantio that she really hates Bianca. Livia is ironic in saying that she sympathizes with Bianca when in fact she is envious and that she wants to do harm on her the reason for pitying and not hating her. Actually, Livia is provoking and expecting Leantio to turn back against Bianca and she just wants to reassure herself whether Leantio really hates Bianca after all what has happened between them as former couple. However, Livia gets upset when Leantio instead accuses her of hating Bianca for no valid reason at all.

This becomes obvious when Livia utters rhetorically, "Hate her?" which is a denial and smacks of insincerity. This is sarcastic though it's of lesser degree than the opposition statement of denial by Livia.

The circumlocutory statement as above is less sincere and less sarcastic than opposition statement and a rhetoric since there's no direct allusion to the speaker's expectation. Even with this statement, there's no any assurance that Livia could be able to change Leantio's mind and feelings towards Bianca that he might be influenced by her assertions. It could be interpreted ironically but of lesser degree depending on whether the hearer or addressee is interested to listen or hear about it.

\section{Context (9): The realization of the dream}

Sordido: Shout help and see.

Bianca (to Mother): $\underline{\text { Run }}$, then, and save me!

Bianca (to Livia): You are a woman. Intervene!

Livia: No, sweet and perfumed thing, we have the same sex, but are not equally women. It's a false sisterhood you seek in me...

Bianca: Oh, utter vileness to wreck this wedding...

Sordido: No, this is proper matrimony! The people marry you! (He seizes her) (P. 56).

Irony: Bianca is totally helpless when Sordido goes towards her, making advances then seizes her. In that desperate situation she turns to Mother who doesn't know what to do and how to react since caught unprepared or just unmindful of the danger befalling on Bianca.

Then finally, while feeling helpless Bianca has forgotten the fact that Livia is the mastermind, does ask Livia to intervene being a woman. It's just a wishful thinking on Bianca's part in case Livia changes mind. 
In the utterance of Bianca, there's always a command, and not a request which just shows that she has gone demanding and arrogant. Has she learned to say 'please', perhaps things would have turned out differently that Livia might even have a change of heart towards her. Even Leantio does not bother to intervene and showing no sympathy but only his feelings of resentment and hatred towards Bianca prevail.

The utterance by Livia of the words 'sweet and perfumed thing' implies contrasting message. It may sound gentle by actually it's like as if there's no giving chance especially when someone flatters you with some compliments that either you can respond or unable to make a reply due to disbelief. This is ironic particularly that Livia is perceived as enemy of Bianca.

\section{Context (10): The betrayal and conspiracy exposed}

Hippolito: Act!

Duke (touching Bianca's exposed neck): Oh, this perfect neck all white with cruelty, it rots - all - calculation Bianca... (He slides down her, to his knees, sobbing.)

Hippolito: Oh, somebody govern! (He goes to take the dagger from the Duke, but the Ward enters.)

Ward: No rush... (he goes to the body of Sordido.) Do you think it hurt him to be killed? He hated life, it was absurd to him.

Hippolito (inspired): Govern the state (P. 60).

Irony: It turns out that Hipolito is the right-hand man of the Duke. The extent of his authority is undetermined until this last episode when he is ordering the Duke to act. Under this circumstance, this order is meant to provoke the Duke to commit an act against his will, to do something that might endanger or compromise his position. Though it has an appearance of legitimacy the order of Hipolito for the Duke might save the sovereignty in short term with all the lies kept temporarily hidden.

On second thought, the order by Hippolito to the Duke to act is ironical. It could mean that the Duke should act, and go on murdering Bianca, that would also result to compromising the Duke's future. Hipolito is far from being a suspect of disloyalty or even a member of Livia's group while not discounting the fact that they are siblings that there could be conspiracy at work.

But even Hipolito and Livia are oftentimes seen having heated argument and at odd with each other. While giving Hippolito the benefit of the doubt, it's apparent that he is unaware of the plan and is put in the dark for some reasons.

First, Hipolito is close to the Duke and Livia might have doubted his loyalty on her, that divulging about the plan might jeopardize or abort the plan even before its execution.

The utterance of words 'somebody govern' by Hippolito implies that someone should govern since the Duke is no longer capable to run the state with his present status. But the irony is that Hippolito is asking for just anyone. How could that be, as if running government is such an easy job that doesn't require experience and qualification.

\section{Results}

The results of this study presented herein reflect a comprehensive view of irony in its various contexts and details. Several significant instances and contexts of irony appear in the play, are presented in series of events as they occur. The contexts are deliberately shown here in sequence so as to make it convenient for the reader to follow through the series. If there is any form of overlapping utterances, it is simply intended at emphasizing or showing the importance and continuity that is deemed necessary.

A lot has been written about irony from many different points of view. As a matter of fact, many short essays and reviews have been repotted about the play, that I have encountered. Some reviews are really informing and constructive, while others are found destructive or too critical of the play. This proves that interpretations as well as appreciation may vary depending on the level of understanding of the reviewer or essayist. However, we cannot pass judgment or doubt their sincerity or credibility. That is why I treat them as independent scholars trying to do their job to their level best .

Meantime, so far, there are no other research I know of that are entirely devoted for processing ironic interpretations of the play. Thus, it is a privilege to study the irony of politeness using presupposing expressions in the play. Though I must admit that it is not an easy job, especially that this play, is heavily laced or loaded with offensive words if not malicious, vulgar or censorious language. Since my main purpose is to interpret irony of polite presuppositions, therefore I have to look at the brighter side or focus on the positive aspects of the story for final reinterpretation. Oftentimes, I have to be neutral or remain at the center and even exercise flexibility, meaning to put myself in the 
position of both speaker and hearer, weighing pros and cons at the same time. In this way, I could pick up any manner and hints of politeness then process and comprehend the meaning then finally interpret in the reverse though not necessarily or strictly its rudeness side but based on acceptable norms and justifiable standards.

\section{Conclusion}

The study of irony using implicit display theory in our ordinary discourse or regular conversation provides a very important guideline in the way it influences and affects our daily lives. But we also acknowledge all other theories of irony are also highly worthy of appreciation as they contribute to a wider scale and scope in learning of irony processing in general.

Even before I have been introduced to undertake this project study about irony and using presupposing expressions, I have already read many references somehow related to the topic of irony. So I have become more interested when I finally started doing actual interpretation or processing of ironic meanings based on the presupposing expressions. To reiterate what Utsumi (2004) is referring to in her report, that irony offers an effective way of accomplishing various communication goals for maintaining and modifying social and interpersonal relationships that are difficult literally. But really, it's not an easy task to interpret ironical meanings. Happe (1993) indicated that irony processing requires higher-order mind reading ability. It has been argued that understanding of irony plays an important role in the interpretation of ordinary utterances (Cited in Wilson and Sperber, 2004).

The prototype-based view permits the implicit display theory to explain the obtained finding that the degree of irony differs among various utterances and contexts. While allusion-based theory such as that of Kumon-Nakamura, Glucksberg, and Brown's (1995), and the echoic interpretation theory such as that of Gibbs and Colston's (2007) cannot explain why overpolite utterances are rated as more ironic than appropriately polite utterances. On the other hand, insincerity-oriented theories such as that of Attardo (2001) which focus on relevant inappropriateness view cannot account for the finding that the speaker's expectation affects the degree of irony.

Furthermore, the echoic interpretation theory also fails to explain the finding that the degree of irony is affected by contextual information only when the speaker's expectation about the addressee's belief triggers irony. The reason for the difficulty in explaining such effect lies in their view that irony interpretively echoes not only the speaker's expectation, but also other sources such as someone's utterances, opinions or even general norms. Whereas the implicit display theory assumes that only the speaker's expectation is alluded to by irony. Therefore, the echoic interpretation theory needs not and indeed does not, assume the speaker's expectation about the addressee's belief to explain irony, but just assumes that irony echoes the general norm.

Therefore, it is concluded that implicit display theory is superior to other theories of irony. Though it must be understood that application of implicit display theory is generally on case to case basis where the role of style and context allows researchers to draw hypotheses about the degree of irony.

Thus, after actual observation and application of implicit display theory in irony processing of contexts for ironies of politeness in the play, it is proven true and therefore concluded that the predictions made on the general hypothesis of implicit display theory have universal application and effect.

As far as I'm concerned, the presupposing contributor to politeness expressions has had its significance and revolves around in almost every aspect of discourse. Thus, "[p]resupposition is interesting as a parameter linked to the way (ideological) beliefs emerge in discourse in two ways:

(a) Through presupposition speakers/authors can manipulate the audience by presenting certain beliefs as true, given and unquestionable, even if they were not known or shared by the audience before (the so-called 'informative presuppositions').

(b) Shared background knowledge necessary for indirect ideological statements to be communicated without being explicitly asserted and justified can surface in discourse indirectly through presupposition. This knowledge may be 'naturalized' ideology in that it is accessed and accepted but not brought to attention/not open to questioning" (Polyzou, 2015, P. 124).

This is why it is very important to learn and realize how the usage of presupposing expressions contribute largely to expressing thoughts and ideas politely and effectively in general. It is noted that all sentences that contain or imply a presupposition that something is assumed to be true. A person cannot communicate effectively if he/she has to prove everything he says all of the time. With presuppositions, at least one part of a sentence must be assumed to be true for the whole sentence to make sense. The point to be learned is how to structure the presuppositions carefully in our statements if we want to be more impressive or to sound more convincing and acceptable. 
The most important research to date is the application of implicit display theory as it offers a more comprehensive view of understanding irony processing as proposed by Utsumi (2004). Along with its detailed general hypothesis, a person will be able to draw or to distinguish the degree of irony from the differential role of style and context.

However, I have adapted this implicit display theory only when and where necessary in the irony processing reported here by applying and satisfying its main threefold claim that: (1) irony presupposes ironic environment, a proper situational setting in the discourse context, (2) irony is an utterance that implicitly displays ironic environment, and (3) irony is a prototype-based category characterized by the notion of implicit display.

I do not claim to have exclusively used the implicit display theory of verbal irony. As a matter of fact, throughout the play, only a few cases are found to have met all the pre-requisites as stated above, i.e., threefold claim to apply this theory freely. For this project report, I have properly identified those areas where the theory is applicable.

I must admit that there are many instances and situations in the play in which I have been encountered with some difficulty in applying the implicit display theory. This has been the case in many ordinary discourse and normal condition and spontaneous utterances. We could hardly sense speaker's expectations unless we are fully familiar with the background. Based on my personal account and observation, irony occurs when there's ambiguity utterances and the intention is not sincere.

\section{References}

Attardo, S. (2001). Humor and Irony in Interaction: From Mode Adoption to Failure of Detection. In L. Anolli, R. Ciceri and G. Riva (Eds.), Say not to Say: New Perspective on Miscommunication, (PP. 165-185). Amsterdam: IOS Press.

Barbe, K. (1995). Irony in Context. Amsterdam: John Benjamins Publishing Company. https://doi.org/10.1075/pbns.34

BeYssade, C. (2013). Back to uniqueness presupposition. Recherches Linguistiques de Vincennes, 42, 123-139. https://doi.org/10.4000/rlv.2190

Brown, P. \& Levinson, S. C. (1987). Politeness: Some Universals in Language Usage. Cambridge: Cambridge University Press.

Garcia-Odon, A. (2016). Presupposition Projection and Conditionalization. Topoi, 35, 145-156. https://doi.org/10.1007/s11245-014-9279-y

Gibbs, R.W. (1994). The Poetics of Minds. Cambridge, England: Cambridge University Press.

Gibbs, R.W. \& Colston, H. L. (2007). Irony in Language and Thought. New York: Lawrence Erlbaum Associates.

Giltrow, J. (1996). Ironies of Politeness in Anita Brookner's Hotel du Lac. In K. Mezei (Ed.), Ambiguous Discourse (PP. 215-237). London: The University of North Carolina Press.

Gussow, M. (1987). Stage: 'Women Beware,' Updated of Jacobean Play. In K. Friedenreich (Ed.), 'Accompaninge the Players': Essays Celebrating Thomas Middleton (PP. 1580-1980). New York: AMS Press. Retrieved from http://www.nytimes.com/glogin?URI=http://theater.nytimes.com/mem/theater/treview.html\&OQ.

Happe, F. (1993). Communicative Competence and Theory of Mind in Autism: A Test of Relevance Theory. Cognition, 48, 101-119. https://doi.org/10.1016/0010-0277(93)90026-R

Jeoung, H. Irony Intended: The Pragmatic Functions of Verbal Irony. Retrieved from http://webcache.googleusercontent.com/search?q=cache:http://jeas.co.kr/attatchup/3-6JEASJHJ.pdf\&safe=activ e.

Kotthoff, H. (1998). Irony, Quotation, and Other Form of Staged Intertextuality: Double or Contrastive Perspectivation in Conversation. Interaction and Linguistic Structures, 5, 1-25.

Kotthoff, H. (2002). Responding to irony in different contexts: On cognition in conversation. Journal of Pragmatics, 35(2003), 1387-1411.

Kumon-Nakamura, S., Glucksberg, S., \& Brown, M. (1995). How about another Piece of Pie: The Allusional Pretense Theory of Discourse Irony. Journal of Experimental Psychology: General, 124, 3-121. https://doi.org/10.1037/0096-3445.124.1.3

Lapp, E. (1992). Linguistic der Ironie. Tübingen: Narr.

Levinson, S. C. (1983). Pragmatics. Cambridge: Cambridge University Press. 
Middleton, T. \& Barker, H. (1989). Women Beware Women/ Pity in History. London and New York: John Calder and Riverrun Press.

Polyzou, A. (2015). Presupposition in Discourse Theoretical and Methodological Issues. Critical Discourse Studies, 12(2), 123-138. https://doi.org/10.1080/17405904.2014.991796

Quintilianus, M. F. (1975). Institutiones oratoriae, hg. und u* bersetzt von Helmut Rahn. Wissenschaftliche Buchgesellschaft, Darmstadt.

Schwarz, F. (2016). Experimental Work in Presupposition and Presupposition Projection. Annu. Rev. Linguist, 2, 273-92. https://doi.org/10.1146/annurev-linguistics-011415-040809

Spector, B. (2016). Multivalent Semantics for Vagueness and Presupposition. Topoi, 35, 45-55. https://doi.org/10.1007/s11245-014-9292-1

Stalnaker, R. (1978). Assertion. In: P. Cole (Ed.), Syntax and Semantics, (PP. 315-322). Academic Press, New York.

10 Pragmalinguistics and Stylistics. Retrieved from http://www.pulib.sk/elpub2/FF/Ferencik/10.pdf

Utsumi, A. (2000). Verbal Irony as Implicit Display of Ironic Environment: Distinguishing Ironic Utterances from Non-ironic. Journal of Pragmatics, 32(12), 1777-1806. https://doi.org/10.1016/S0378-2166(99)00116-2

Utsumi, A. (2004). Stylistic and Contextual Effects in Irony Processing. Retrieved from http://www.google.com/url?sa=D\&q=http://www.utm.se.uec.ac.jp/ utsumi/paper/cogsci2004-utsumi.pdf\&usg= AFQjCNFalytqIYk1S5HJ45nCKvbCOdqWBw

Wilson, D. \& Sperber, D. (2004). Relevance Theory. In L. Horn and G. Ward (Eds.), Handbook of Pragmatics, (PP.607-632). Oxford: Basil Blackwell. 